\title{
Economic Evaluation of Drip Irrigation System in Bell pepper (Capsicum annum L var. grossum) Grown under Naturally Ventilated Polyhouse
}

\author{
Sajal Debbarma*, Lalit Bhatt, S.K. Maurya, Dhirendra Singh and P.K. Singh \\ Department of Vegetable Science, Govind Ballabh Pant University of Agriculture and \\ Technology, Pantnagar, Uttarakhand, India \\ *Corresponding author
}

\section{A B S T R A C T}

\section{Keywords}

Drip irrigation, Bell pepper, Black plastic mulch, Economics, Benefit cost ratio.

Article Info

Accepted:

17 September 2017 Available Online: 10 November 2017
A field experiment was conducted in the year 2014-2015 to study the effect of drip irrigation levels and black plastic mulch on bell pepper production under naturally ventilated polyhouse. The experiment was carried out in Randomized Block Design with four drip irrigation levels (100, 80, 60 and $40 \%$ of crop water requirement) and surface irrigation in conjunction with or without plastic mulch. Better results were found in drip irrigation system as compared to surface irrigation both under mulched and unmulched treatment. As far as net return and Benefit Cost ratio was concerned, maximum net return of Rs $19,026.04 / 100 \mathrm{~m}^{2}$ and benefit cost ratio of 2.56 was noticed in treatment receiving irrigation at 80 percent crop water requirement through drip system under plastic mulch.

\section{Introduction}

Bell pepper (Capsicum annum L. var. grossum, $2 \mathrm{n}=2 \mathrm{x}=24$ ), also known as sweet pepper or capsicum or Shimla mirch, is a popular vegetable belongs to the family Solanaceae. Despite its economic importance, production of good quality capsicum under open field condition is not easy due to its specific climatic requirements. Lower and higher temperature, high rainfall, hails, frost, water logging and higher relative humidity are major limiting factors for successful cultivation of capsicum under open field condition However, and it can successfully be cultivated under protected condition. Water management in bell pepper is extremely important assoil moisture stress during the growing period reduces the yield and quality. Presently, the water has become scarce natural resource due to rapid population growth, industrialization, urbanization and erratic rainfall. Therefore, the irrigation water is also becoming both scarce and expensive due to fast depletion of surface and subsurface water resources, hence precious use of water is the need of the hour. Keeping in view the above concerns and to achieve higher returns from per unit area judicious use of irrigation water through drip system along with plastic mulch in naturally ventilated polyhouse has become inevitable. Major 
drawback of drip irrigation $\mathrm{s}$ is that it requires additional capital investment due to which farmers are generally reluctant to adopt this technology; however, cost can be recovered in a short span if proper water management and design principles are followed. Many scientists reported that drip irrigation in bell pepper is economical by maximum return and maximum yield. Keeping these facts in view, present investigation was carried out to study the economic viability of drip irrigation system in bell pepper under naturally ventilated polyhouse.

\section{Materials and Methods}

The present study was carried out at Vegetable Research Centre of G.B. Pant University of Agriculture and Technology, Pantnagar (Uttarakhand) during cropping season of September 2014 to May 2015.The experiment consisting of 10 treatments was laid out in randomized block design with three replications. The treatments were irrigation at $100 \%$ crop water requirement without black plastic mulch $\left(\mathrm{T}_{1}\right)$, irrigation at $100 \%$ crop water requirement with black plastic mulch $\left(\mathrm{T}_{2}\right)$, irrigation at $80 \%$ crop water requirement without black plastic mulch $\left(\mathrm{T}_{3}\right)$, irrigation at $80 \%$ crop water requirement with black plastic mulch $\left(\mathrm{T}_{4}\right)$, irrigation at $60 \%$ crop water requirement without black plastic mulch $\left(\mathrm{T}_{5}\right)$, irrigation at $60 \%$ crop water requirement with black plastic mulch $\left(\mathrm{T}_{6}\right)$, irrigation at $40 \%$ crop water requirement without black plastic mulch, $\left(\mathrm{T}_{7}\right)$, irrigation at $40 \%$ crop water requirement with black plastic mulch $\left(\mathrm{T}_{8}\right)$, Surface irrigation without black plastic mulch $\left(\mathrm{T}_{9}\right)$ and Surface irrigation with black plastic mulch $\left(\mathrm{T}_{10}\right)$.

The volume of water for $100 \%$ crop water requirement based on pan evaporation was

Computed using the following equation.
$\mathrm{V}=\mathrm{Ep} \times \mathrm{Kp} \times \mathrm{Kc} \times \mathrm{Sp} \times \mathrm{Sr} \times \mathrm{Wp}$

Where, $\mathrm{V}=$ Water requirement of plant per day (1), $\mathrm{Ep}=\mathrm{PAN}$ evaporation, $\mathrm{Kp}=\mathrm{Pan}$ Coefficient, $\mathrm{Kc}=\mathrm{Crop}$ coefficient varies according to growth, $\mathrm{Sp}=$ Plant to plant spacing $(\mathrm{m}), \mathrm{Sr}=$ Row to Row spacing (m), $\mathrm{Wp}=$ Fraction wetted area

Before transplanting of crop, the experimental field was well prepared with the help of spade followed by breaking of clods and levelling. After levelling, the field was divided into plots with walking channels in between the plots. After field preparation $15 \mathrm{~cm}$ raised beds of $150 \mathrm{~cm}$ width were made and over these, black plastic mulch of 40 micron was spread according to the treatments and their corners and sides were covered with soil. Holes were made at a spacing of $60 \times 50 \mathrm{~cm}$ for easy transplanting of seedlings. Healthy seedlings of capsicum cv. Indira were transplanted in polyhouse on $17^{\text {th }}$ October, 2014. Once seedlings were established, thereafter for raising healthy crop, all the necessary recommended cultural and plant protection operations were followed. After taking into consideration of variables, fixed input and their corresponding rates, the cost incurred under each treatment was worked out for an area of $100 \mathrm{~m}^{2}$. To get gross return/ha, the fruit yield ( $\mathrm{t} / \mathrm{ha}$ ) obtained in each treatment was multiplied with prevailing local mandi rates. Net return in each treatment was calculated by subtraction of cost of cultivation from the gross return. Benefit-Cost ratio was computed in each treatment with division of gross return by cost of cultivation.

\section{Results and Discussion}

From the table it is evident that the drip irrigation in combination with mulch significantly increased the yield of capsicum as compared to drip irrigation without mulch and surface irrigation. Among various 
treatments the highest yield of 88.99 t/ha was recorded by providing irrigation at 80 percent of crop water requirement in black plastic mulched plots and is 31.27 percent and 15.91 percent higher than surface irrigation under unmulched and mulched condition, respectively. Use of plastic mulching also have significant impact in increasing the yield and use of mulching alone increase the yield by 6.93 percent and 14.59 percent in case of 80 percent of irrigation water supplied through drip and surface irrigation, respectively.

Higher uptake of nutrients (Bafna et al., 1993) and excellent soil-water relationship with higher oxygen concentration in the root zone (Gornat et al., 1973) contributed to higher yield under drip irrigation with favourable moisture. Swarajyalakshmi et al., (2005) reported that the highest green chilli yield was recorded through drip method scheduled at 0.8 ET under black polythene mulch. Minimum yield was recorded under surface irrigation method may be attributed to the water stress during the critical growth period, coupled with aeration problem due to application of excess of irrigation water besides less availability of nutrients for crop growth due to leaching with high weed infestation between the crops (Pattanaik et al., 2003).

Cost of cultivation was worked out for $100 \mathrm{~m}^{2}$ area taking consideration prevalent wages and rates of critical inputs in the area of study for each treatment under naturally ventilated polyhouse. In the present investigation, highest cost of cultivation (Rs.12341.00) was noticed in those condition where plant receives irrigation at 100 percent water requirement under unmulched condition (Rs.12341.00) followed by irrigation at 80 percent water requirement without black plastic mulch (Rs.12305.46). On the other hand minimum cost of cultivation of Rs.11857.80 was recorded under surface irrigation with black plastic mulch $\left(\mathrm{T}_{10}\right)$.

Data depicted in Table clearly shows that all the treatments without black plastic mulch recorded higher cost of cultivation than treatments with black plastic mulch because longer duration crop of capsicum under naturally ventilated polyhouse involve higher cost in weeding operation and better management of resources than corresponding black plastic mulched treatments.

Table.1 Effect of different drip irrigation levels and black plastic mulch on economics of capsicum under naturally ventilated polyhouse for an area of $100 \mathrm{~m}^{2}$

\begin{tabular}{cccccc}
\hline Treatments & $\begin{array}{c}\text { Average } \\
\text { Yield/hectare }(\mathbf{t})\end{array}$ & $\begin{array}{c}\text { Cost of cultivation } \\
\left(\mathbf{R s} / \mathbf{1 0 0} \mathbf{~ m}^{\mathbf{2}}\right)\end{array}$ & $\begin{array}{c}\text { Gross return } \\
\left(\mathbf{R s} / \mathbf{1 0 0} \mathbf{~ m}^{\mathbf{2}}\right)\end{array}$ & $\begin{array}{c}\text { Net return } \\
\left(\mathbf{R s} / \mathbf{1 0 0} \mathbf{~ m}^{\mathbf{2}}\right)\end{array}$ & B-C \\
\hline $\mathrm{T}_{1}$ & 80.66 & 12341.00 & 28,231 & 15,890 & 2.28 \\
$\mathrm{~T}_{2}$ & 86.66 & 12161.00 & 30,331 & 18,170 & 2.49 \\
$\mathrm{~T}_{3}$ & 83.22 & 12305.46 & 29,127 & $16,821.54$ & 2.36 \\
$\mathrm{~T}_{4}$ & 88.99 & 12120.46 & $31,146.5$ & $19,026.04$ & 2.56 \\
$\mathrm{~T}_{5}$ & 82.44 & 12254.72 & 28,854 & $16,599.28$ & 2.35 \\
$\mathrm{~T}_{6}$ & 87.88 & 12069.72 & 30,758 & $18,688.28$ & 2.54 \\
$\mathrm{~T}_{7}$ & 77.66 & 12193.91 & 27,181 & $14,987.09$ & 2.22 \\
$\mathrm{~T}_{8}$ & 82.33 & 12008.91 & $28,815.5$ & $16,806.59$ & 2.39 \\
$\mathrm{~T}_{9}$ & 66.99 & 12027.80 & $23,446.5$ & $11,418.7$ & 1.94 \\
$\mathrm{~T}_{10}$ & 76.77 & 11857.80 & $26,869.5$ & $15,011.7$ & 2.26 \\
$\mathrm{CD}$ at $5 \%$ & 2.66 & & & & \\
\hline
\end{tabular}


Table.2 Average cost of cultivation $\left(\mathrm{Rs} / 100 \mathrm{~m}^{2}\right)$ of capsicum irrigated with different drip irrigation levels and black plastic mulch under naturally ventilated polyhouse based on fixed cost and variable cost

\begin{tabular}{|c|c|c|c|c|}
\hline Sl. No. & Particulars & Quantity & Price/unit & Amount (Rs) \\
\hline $\mathbf{A}$ & Fixed costs & \multirow{7}{*}{25} & \multirow{12}{*}{$500 / \mathrm{m}^{2}$} & \\
\hline 1.i) & $\begin{array}{l}\text { Naturally ventilated } \\
\text { polyhouse }\end{array}$ & & & 55,000 \\
\hline a) & Life(years) & & & \\
\hline b) & Depreciation@10\% & & & \\
\hline c) & Interest @12\% & & & 1980 \\
\hline ii) & Polysheet (200 micron UV & & & 6600 \\
\hline & $\begin{array}{l}\text { stabilized transparent } \\
\text { polysheet) }\end{array}$ & & & 10000 \\
\hline d) & Life(years) & \multirow[t]{5}{*}{5} & & \\
\hline e) & Depreciation@10\% & & & 1800 \\
\hline f) & Interest @12\% & & & 1200 \\
\hline g) & Total $(b+c+e+f)$ & & & 11580 \\
\hline h) & Total cost for 8 months & & & 7720 \\
\hline 2. & Drip irrigation system & \multirow{6}{*}{10} & & 7000 \\
\hline a) & Life(years) & & & \\
\hline b) & Depreciation@10\% & & & 630 \\
\hline c) & Interest @12\% & & & 840 \\
\hline d) & Total $(b+c)$ & & & 1470 \\
\hline e) & Total cost for 8 months & & & 980 \\
\hline 3 & Black plastic mulch (40 & \multirow{7}{*}{1} & $6 / \mathrm{m}^{2}$ & 360 \\
\hline & micron) & & & \\
\hline a) & Life(years) & & & \\
\hline b) & Depreciation@10\% & & & 324 \\
\hline c) & Interest@12\% & & & 43.2 \\
\hline d) & Total $(b+c)$ & & & 367.2 \\
\hline e) & Total cost for 8 months & & & 244.8 \\
\hline 4. & Operational cost & & & \\
\hline a) & $\begin{array}{l}\text { Land preparation } \\
\text { (by labour) }\end{array}$ & $\begin{array}{c}1 \text { labour for } 1 / 2 \\
\text { day }\end{array}$ & 200 & 100 \\
\hline b) & Nursery raising & $\begin{array}{c}1 \text { labour for } 4 \\
\text { hours }\end{array}$ & 200 & 100 \\
\hline c) & Interculture operations & $\begin{array}{c}1 \text { labour for } 2 \\
\text { days }\end{array}$ & 200 & 400 \\
\hline d) & Transplanting & $\begin{array}{c}1 \text { labour for } 2 \\
\text { hours }\end{array}$ & 200 & 50 \\
\hline e) & Irrigation (105 Nos) & $\begin{array}{c}1 \text { labour for } 1 / 2 \\
\text { hour }\end{array}$ & 200 & $1,312.5$ \\
\hline f) & $\begin{array}{l}\text { Plant protection spray ( } 5 \\
\text { Nos) }\end{array}$ & $\begin{array}{c}1 \text { labour for } 1 / 2 \\
\text { hour }\end{array}$ & 200 & 62.5 \\
\hline g) & Pickings (10 Nos) & 1 labour for $1 / 2$ & 200 & 125 \\
\hline
\end{tabular}




\begin{tabular}{|c|c|c|c|c|}
\hline h) & Total operational cost & hour & & 2150 \\
\hline $\begin{array}{l}5 . \\
\text { a) } \\
\text { b) } \\
\text { c) } \\
\text { d) } \\
\text { e) }\end{array}$ & $\begin{array}{l}\text { Material cost } \\
\text { Seed } \\
\text { Plant protection chemicals } \\
\text { Fertilizer cost. } \\
\text { FYM } \\
\text { Total material cost }\end{array}$ & $3.5 \mathrm{~g}$ & $480 / 10 \mathrm{~g}$ & $\begin{array}{c}168 \\
180 \\
130 \\
50 \\
528\end{array}$ \\
\hline 6. & $\begin{array}{l}\text { Total cost for } 8 \text { months. (1h } \\
+2 \mathrm{e}+3 \mathrm{e}+4 \mathrm{~h}+5 \mathrm{e})\end{array}$ & & & $11,622.8$ \\
\hline
\end{tabular}

Table.3 Treatment wise variable cost of capsicum production under naturally ventilated polyhouse

\begin{tabular}{|l|c|c|c|c|c|c|c|c|}
\hline Treatments & $\begin{array}{c}\text { Water } \\
\text { applied } \\
\text { (mm) }\end{array}$ & $\begin{array}{c}\text { Motor } \\
\text { running } \\
\text { (hrs) }\end{array}$ & $\begin{array}{c}\text { Electricity } \\
\text { charges }\end{array}$ & $\begin{array}{c}\text { Weeding } \\
\text { cost }\end{array}$ & $\begin{array}{c}\text { Yield } \\
\text { (kg) } \\
\mathbf{1 0 0} \mathbf{m}^{2}\end{array}$ & $\begin{array}{c}\text { No. of } \\
\text { crates }\end{array}$ & $\begin{array}{c}\text { Transportation } \\
\text { charges }\end{array}$ & $\begin{array}{c}\text { Total } \\
\text { cost }\end{array}$ \\
\hline $\mathbf{T}_{\mathbf{1}}$ & 470.4 & 33.02 & 268.20 & 200 & 806.6 & 50 & 250 & 768.2 \\
$\mathbf{T}_{\mathbf{2}}$ & 470.4 & 33.02 & 268.20 & - & 866.6 & 54 & 270 & 538.20 \\
$\mathbf{T}_{\mathbf{3}}$ & 376.3 & 27.41 & 222.66 & 200 & 832.2 & 52 & 260 & 682.66 \\
$\mathbf{T}_{\mathbf{4}}$ & 376.3 & 27.41 & 222.66 & - & 889.9 & 55 & 275 & 497.66 \\
$\mathbf{T}_{\mathbf{5}}$ & 282.2 & 21.78 & 176.92 & 200 & 824.4 & 51 & 255 & 631.92 \\
$\mathbf{T}_{\mathbf{6}}$ & 282.2 & 21.78 & 176.92 & - & 878.8 & 54 & 270 & 446.92 \\
$\mathbf{T}_{\mathbf{7}}$ & 188.1 & 16.14 & 131.11 & 200 & 776.6 & 48 & 240 & 571.11 \\
$\mathbf{T}_{\mathbf{8}}$ & 188.1 & 16.14 & 131.11 & - & 823.3 & 51 & 255 & 386.11 \\
$\mathbf{T}_{\mathbf{9}}$ & 470.4 & - & - & 200 & 669.9 & 41 & 205 & 405.00 \\
$\mathbf{T}_{\mathbf{1 0}}$ & 470.4 & - & - & - & 767.7 & 47 & 235 & 235.00 \\
\hline
\end{tabular}

The gross return was calculated taking care of average selling price of produce whereas the net profit was worked out from gross return and total cost of cultivation for each treatment. None of the treatments were found negative in their net income. Economic analysis of different treatments in $100 \mathrm{~m}^{2}$ area of naturally ventilated polyhouse shows that maximum gross return of Rs. 31,146.5 along with highest net return of Rs. 19,026.04 and benefit- cost ratio of 2.56 was obtained from by irrigation capsicum crop with 80 percent water requirement along with black plastic mulch $\left(\mathrm{T}_{4}\right)$ followed by irrigation at 60 percent water requirement with black plastic mulch i.e. Rs. 30,758, Rs.18,688.28 and 2.54, respectively. Minimum gross return of Rs. 23,446.5, net return of Rs. 11,418.7 and benefit cost ratio of 1.94 was obtained from surface irrigation without black plastic mulch. 
During the study use of black plastic mulch was observed better in getting higher benefit cost ratio than traditional practices of open field condition.

Increasing and decreasing the irrigation water above and below 80 percent of crop water requirement decreased the benefit cost ratio. The increase in the value of gross return, net profit and benefit cost ratio at 80 percent crop water requirement with black mulch could be attributed to higher yield under optimum moisture supply and favourable microclimate in the root zone under mulched with black plastic mulch. Similar results in terms of gross return, net return and benefit cost ratio were obtained by Paul et al., (2013) in capsicum and Biswas et al., (2015) in tomato.

Higher benefit cost ratio in case of drip irrigation system suggests the better returns from drip irrigation system. Based on the findings of present study, it could be concluded that irrigation of capsicum at 80 percent water requirement with black plastic mulch was the most profitable in getting higher yield ( $88.99 \mathrm{t} / \mathrm{ha})$ and benefit cost ratio (2.56) under naturally ventilated polyhouse. Hence, drip irrigation system is economically viable in capsicum under naturally ventilated polyhouse.

\section{References}

Bafna, A.M., Daftardar, S.Y., Khade, K.K., Patel, P.V. and Dhotre, R.S. 1993. Utilization of nitrogen and water by tomato under drip irrigation system. Journal of Water Management. 1(1), 15.

Biswas, S.K., Akanda, A.R., Rahman, M.S. and Hossain, M.A. 2015. Effect of drip irrigation and mulching on yield, wateruse efficiency and economics of tomato. Plant Soil and Environment. 61(3), 97102.

Gornat, B., Goldberg, D, Rimon, D. and Asher, B.J. 1973. The physiological effect of water quality and method of application on tomato, cucumber and pepper. Journal of American Society of Horticultural Science. 98(2), 202-205.

Pattanaik, S.K., Sahu, N.N., Pradhan, P.C. and Mohanty, M.K. 2003. Response of Banana to drip irrigation under different irrigation designs. Journal of Agricultural Engineering. 40(3), 29-34.

Paul J. C., Mishra, J.N., Pradhan, P.L. and Panigrahi, B. 2013. Effect of drip and surface irrigation on yield, water-useefficiency and economics of capsicum (Capsicum annum L.) grown under mulch and non-mulch conditions in eastern coastal India. European Journal of Sustainable Development. 2(1), 99108.

Swarajyalakshmi, K.M., Reddy, D.M., Shivashankar, M., Suresh Babu, K. and Nageswara, R.P. 2005. Studies on response of chilli to different levels of drip irrigation and mulching as compared to basin method of irrigation. In: International conference on plasticulture and precision farming, New Delhi, India.

\section{How to cite this article:}

Sajal Debbarma, Lalit Bhatt, S.K. Maurya, Dhirendra Singh and Singh, P.K. 2017. Economic Evaluation of Drip Irrigation System in Bell pepper (Capsicum annum L var. grossum) Grown under Naturally Ventilated Polyhouse. Int.J.Curr.Microbiol.App.Sci. 6(11): 2463-2468. doi: https://doi.org/10.20546/ijcmas.2017.611.289 